\title{
Accumulating Japanese popular culture: media consumption experiences of Malaysian young adults
}

\begin{abstract}
The purpose of this study was to understand the experiences of media consumption of Japanese popular culture among Malaysian young adults. Such a study is important in order to understand the consequence of the consumption of foreign cultural products since the development of information and communication technology has brought changes to media entertainment consumption styles, especially among the younger generation. This article discusses the áccumulationô of Japanese popular culture as part of media consumption experiences. Through the interpretation of some young Malaysiansô experiences, the accumulation was found to be an important part of media consumption in developing the young Malaysiansômindset towards specific formats, genres or products from Japan despite the differences that exist between the lifestyles of the Japanese and the Malaysians. The paper highlights that the contents of Japanese popular cultural products are crucial. Without a sophisticated depiction of ón essential human aspectô to which young Malaysians could relate, Japanese popular culture would not be well-liked.
\end{abstract}

